\title{
Forage substitution with MOIYL fermented cacao pod on carcass quality of local sheeps
}

\author{
S D Mahyana, Hasnudi, I Sembiring, S Umar, Yunilas \\ Animal Production Program Study, Faculty of \\ Agriculture, University of North Sumatera, Medan 20155, \\ Indonesia E-mail: mahyanadewi@gmail.com
}

\begin{abstract}
Agriculture waste such as acao pod are abundant. This study aims to determine local sheeps carcass quality after feeding Moiyl fermented cacao pod (Theobroma cacao L) in rations as alternative feed. The research was carried out at Mr. Didit's farm located on Bunga Rinte street, Medan Tuntungan sub district, Medan in October-December 2018. The experiment used was a completely randomized design (CRD) with 5 treatments and 4 replications. Using 20 local rams with an average of $12.65 \pm 1 \mathrm{~kg} /$ head. Treatment consists of forages, and concentrated ingredients such as coconut cake, soybean meal, rice bran, molasses, urea, mineral mix, and Moiyl pod cacao fermented P0 (forage $80 \%+$ concentrate 20\%), P1 (forage 60\% + Pod cacao fermentation 20\% + Concentrate 20\%), P2 (Forage 40\% + Pod cacao fermented $40 \%$ + Concentrate 20\%), P3 (Forage 20\% + Pod cacao fermented 60\% + Concentrate 20\%), P4 (Pod 80\% fermented cacao + Concentrate 20\%).

The results showed that the average cutting weight $\mathrm{P} 0=15.70, \mathrm{P} 1=15.98, \mathrm{P} 2=17.55, \mathrm{P} 3=$ 16.27, $\mathrm{P} 4=14.73,(\mathrm{~kg} /$ head). The average body weight is $\mathrm{P} 0=9.75, \mathrm{P} 1=10.27, \mathrm{P} 2=10.52$, $\mathrm{P} 3=10.14, \mathrm{P} 4=9.18,(\mathrm{~kg} / \mathrm{head})$. The average carcass weight $\mathrm{P} 0=5.36, \mathrm{P} 1=5.61, \mathrm{P} 2=$ $5.74, \mathrm{P} 3=5.73, \mathrm{P} 4=5.73(\mathrm{~kg} / \mathrm{head})$. The average carcass percentage $\mathrm{P} 0=56.51, \mathrm{P} 1=55.55$, $\mathrm{P} 2=54.71, \mathrm{P} 3=56.55, \mathrm{P} 4=51.48(\mathrm{~kg} / \mathrm{head})$. The conclusion of this study is MOIYL fermented cacao pod (Theobroma cacao L) can substitute forage as feed for male local sheep and influenced cutting weight, average body weight, average carcass weight and also average arcass percentage.
\end{abstract}

\section{Introduction}

Cacao production in Indonesia is currently increasing because it is in line with government programs to improve cacao crop development. During the last five years cacao production has continued to increase by 7.14\% per year or 49,200 tons in 2004 (Syriac, 2007)[1].This cacao fruit skin waste has a significant role and is quite potential in providing feed ingredients for ruminants, especially during the dry season. In the dry season grass growth is hampered, so that the availability of forage feed materials is lacking and the quality is low. As a result, there is a shortage of forage, given the limited availability of forage, the strategic step that our data takes is utilizing cacao fruit skin waste for animal feed.Cacao fruit skin has the following nutritional content: $88 \%$ BK, PK 8\%, Sk 40\%, TDN 50.8\%. And use by ruminants is $30-40 \%$ (Sunanto, 1995) [2]. 


\section{Materials and Methods}

\subsection{Time and Place of Research}

This research was conducted at Mr. Didit's sheep farm located on J1. BungaRinte, SimpangSelayang, Medan. This research took place in October - December 2018.

\subsection{Cut Weight ( $k g$ / head)}

Cut weight is body weight after being fasted for 12 hours just before the sheep is slaughtered

\subsection{Blank Body Weight ( $\mathrm{kg} / \mathrm{head})$}

The weight of an empty body is the weight of cattle cut minus the amount of digestive tract contents, the content of urine (urine).

\subsection{Carcass weight $(\mathrm{kg} / \mathrm{head})$}

Carcass weight was measured by weighing the sheep after being slaughtered after deducting the head, blood, four lower legs, skin and inner contents (rumen, intestine, kidney, lung and liver) (Coal, 2002).[3].

\subsection{Carcass percentage ( $\mathrm{kg} / \mathrm{head})$}

The carcass percentage is calculated by dividing the fresh carcass weight with the empty body weight, then multiplying by $100 \%$

\section{Carass percenage = $\quad$ Fresh carcass weight \\ Empty body weight}

\section{Results and Discussion}

\subsection{Lamb Cut Weight}

Cutting weight was obtained from the results of weighing the final weight of the sheep after being fasted for 12 hours before being slaughtered, this is done to empty the contents of the digestive tract. The average slaughter weight of sheep can be seen in table 1 .

Table 1. Average male local sheep cut weight $(\mathrm{kg} / \mathrm{head})$

\begin{tabular}{|c|c|c|c|c|c|}
\hline \multirow{2}{*}{ Perlakuan } & \multicolumn{4}{|c|}{ Ulangan } & \multirow{2}{*}{ Rataan } \\
\hline & U1 & $\mathrm{U} 2$ & U3 & $\mathrm{U} 4$ & \\
\hline $\mathrm{PO}$ & 15,38 & 14,72 & 15,86 & 16,85 & $15,70 \pm 0,89$ \\
\hline P1 & 15,32 & 15,17 & 17,95 & 15,48 & $15,98 \pm 1,31$ \\
\hline P2 & 19,72 & 16,22 & 18,69 & 15,59 & $17,55 \pm 1,96$ \\
\hline P3 & 16,02 & 15,52 & 17,43 & 16,14 & $16,27 \pm 0,81$ \\
\hline $\mathrm{P} 4$ & 14,86 & 13,87 & 15,15 & 15,06 & $14,73 \pm 0,58$ \\
\hline Total & 81,30 & 75,50 & 85,08 & 79,12 & \\
\hline Rataan & 16,26 & 15,10 & 17,01 & 15,82 & 16,05 \\
\hline
\end{tabular}

From Table 1. it can be seen that the highest average slaughter weight of sheep in P2 treatment is 17.55 (kg / head) and the lowest slaughter weight of sheep is in treatment P4 of 14.73 (kg / head).Daily weight gain $(\mathrm{PBBH})$ in this study ranged from $84 \mathrm{~g}$ higher than the yield of PBBH obtained in the range of $81 \mathrm{~g}$. This result has not reached the target of $100 \mathrm{~g} /$ head. This is due to sub-standard energy consumption. Consumption of protein that has met the needs of goats is not followed by the availability of energy for growth. One of the factors that influence slaughter weight is the nation's livestock factor, besides that feed consumption is also influential. Statistical analysis shows that 
different feeding methods do not cause significant differences in feed consumption. This is reinforced by the statement Andiwinati et al. (1999)[4]. which states that the same amount of nutrient consumption of feed will produce the same cutting weight, in addition to the weight of the weight of the empty body also influences.

This is strongly related to the nutrients contained in the feed and the digestibility level of the feed. Rations that have high nutritional value and good levels of palatability can quickly increase animal weight gain during fattening. Giving crude fiber too high will reduce the digestibility of the ration

.Food consumption is influenced mainly by food quality factors and by the factors of the energy needs of the livestock concerned. The better the quality of food, the higher the food consumption of a livestock, but the consumption of good quality livestock food is determined by the physiological status of an animal. To find out the effect of giving from the fermentation on the slaughter.

Table 2. Analysis of the variety of male local sheep cut weights

\begin{tabular}{ccccccc}
\hline SK & Db & JK & KT & F Hitung & \multicolumn{2}{c}{ F tabel } \\
\cline { 6 - 7 } & & & & & $5 \%$ & $1 \%$ \\
\hline Perlakuan & 4 & 16,68 & 4,17 & $2,80^{\mathrm{In}}$ & 3,24 & 5,29 \\
Galat & 15 & 22,28 & 1,48 & & & \\
\hline Total & 19 & 38,96 & & & & \\
\hline
\end{tabular}

The results of the variance analysis in Table 2. show that substitution of MOIYL fermented cacao pods has no significant effect on cutting weight.This is because the provision of fermented cacao pods with MOIYL given to the treatment has an effect on the contents of the digestive tract in sheep where the level of providing fermented pods with MOIYL has been optimum so that the nutrients needed by livestock are fulfilled. This is in accordance with the statement of Siregar (1994) [5].which states that the ration of ruminants is generally forage and concentrate, the provision of rations in the form of a combination of both materials will provide an opportunity for the fulfillment of nutrients. But the ration can also consist of forages and concentrates only, if the ration consists of forage then the costs are relatively cheap, but high production is difficult to achieve while the provision of rations consisting only of concentrates will allow for higher production, but relatively expensive and possibly indigestion occurs.

\subsection{Blank Body Weight}

The body weight of the study was obtained from cutting weight minus the contents of the digestive tract and urine. Where the average body weight is shown in table 3 .

Table 3. Average weight of empty body of male local sheep $(\mathrm{kg} /$ head $)$

\begin{tabular}{cccccc}
\hline \multirow{2}{*}{ Perlakuan } & \multicolumn{4}{c}{ Ulangan } & \multirow{2}{*}{ Rataan } \\
\cline { 2 - 4 } & U1 & U2 & U3 & U4 & \\
\hline P0 & 9,59 & 9,22 & 9,97 & 10,25 & $9,75^{\mathrm{ab}} \pm 0,44$ \\
P1 & 9,56 & 9,74 & 11,04 & 10,76 & $10,27^{\mathrm{a}} \pm 0,73$ \\
P2 & 11,28 & 10,08 & 10,85 & 9,89 & $10,52^{\mathrm{a}} \pm 0,65$ \\
P3 & 9,92 & 9,87 & 10,97 & 9,82 & $10,14^{\mathrm{a}} \pm 0,55$ \\
P4 & 9,13 & 9,02 & 9,36 & 9,24 & $9,18^{\mathrm{b}} \pm 0,14$ \\
\hline Total & 49,48 & 47,93 & 52,19 & 49,96 & \\
\hline Rataan & 9,89 & 9,58 & 10,43 & 9,99 & 9,97 \\
\hline
\end{tabular}

From table 3. the highest average weight of sheep empty body is found in P2 treatment of $10.52(\mathrm{~kg} /$ head) and the lowest empty body weight is found in treatment P4 of 9.18 (kg / head). In this study P2 treatment has a higher cut weight and followed by a higher empty body weight, indicating that cutting 
weight has a positive correlation with empty body weight. The higher the slaughter weight of the sheep the higher the weight value of the empty body. Yuniarti (1982)[6]. shows that increasing weight gain results in an increase in empty body weight.To find out the effect of MOIYL fermented cacao pod on rations on empty body weights can be seen in table 4 .

Table 4. Analysis of the variance of the weight of empty bodies of male local sheep.

\begin{tabular}{ccccccc}
\hline \multirow{2}{*}{ SK } & \multirow{2}{*}{ Db } & JK & KT & F & \multicolumn{2}{c}{ F tabel } \\
\cline { 6 - 7 } & & & & Hitung & $5 \%$ & $1 \%$ \\
\hline Perlakuan & 4 & 4,35 & 1,08 & 3,64 & 3,24 & 5,29 \\
Galat & 15 & 4,47 & 0,29 & & & \\
\hline Total & 19 & 8,83 & & & & \\
\hline
\end{tabular}

The results of the diversity analysis in Table 4. show that $\mathrm{F}$ count is greater than $\mathrm{F}$ table so it is concluded that forage substitution with moiyl fermented cacao pods in rations on carcass quality of male local sheep has a significant effect $(\mathrm{P}<0.05)$ on empty body weight. This can be concluded because each treatment gives a response that is not of the same quality to the weight of an empty body. 3.3 CarcassWeight

Carcass weight is the weight obtained from the difference in body weight after fasting (cut weight) with the weight of blood, head, head, feet, skin, internal organs (besides the kidneys), reproductive organs and tail. The average carcass weight data can be seen in table 5 .

Table 5. Average weight of male local sheep carcass (kg / head)

\begin{tabular}{|c|c|c|c|c|c|}
\hline \multirow[b]{2}{*}{ Perlakuan } & \multicolumn{4}{|c|}{ Ulangan } & \multirow{2}{*}{ Rataan } \\
\hline & U1 & $\overline{\mathrm{U} 2}$ & $\mathrm{U} 3$ & $\mathrm{U} 4$ & \\
\hline P0 & $\overline{5,46}$ & $\overline{5,05}$ & 5,14 & 5,82 & $5,36^{\mathrm{a}} \pm 0,34$ \\
\hline P1 & 5,43 & 5,01 & 5,97 & 6,06 & $5,61^{\mathrm{a}} \pm 0,49$ \\
\hline $\mathrm{P} 2$ & 5,61 & 6,02 & 5,52 & 5,79 & $5,74^{\mathrm{a}} \pm 0,66$ \\
\hline P3 & 5,54 & 5,91 & 6,56 & 4,98 & $5,73^{\mathrm{a}} \pm 0,22$ \\
\hline P4 & 4,56 & 4,46 & 4,99 & 4,92 & $4,73^{\mathrm{b}} \pm 0,26$ \\
\hline Total & 26,6 & 26,45 & 28,18 & 27,57 & \\
\hline Rataan & 5,32 & 5,29 & 5,63 & 5,51 & 5,44 \\
\hline
\end{tabular}

From table 5. it can be seen that the highest carcass weight is found in $\mathrm{P} 2$ treatment which is equal to $5.74(\mathrm{~kg})$ and the lowest average carcass weight is $\mathrm{P} 4$, which is $4.73(\mathrm{~kg})$, this carcass weight is higher than the obtained carcass weight where the highest weight is equal to $3.99(\mathrm{~kg})$ with the treatment of physically biologically treated rice straw (Aspergillusniger). Concentrate mixed by cacao pods is added and the lowest carcass weight is $3.65(\mathrm{~kg})$.

The treatment of chemically treated rice straw $(\mathrm{NaOH})$ is added with concentrates mixed with cacao pods. The production of carcass weights from each treatment showed different results. The researchers assumed that this was influenced by the live weight of sheep, the sheep's weight was influenced by the nutritional content and composition of feed consumed by sheep. This is consistent with the statement], which states that the more the sheep's weight increases, the carcass production also increases. The weight of sheep carcass is also influenced by the age of livestock, where the age of livestock used is almost uniform.

Factors that influence carcass composition and meat quality are gender and slaughter weight. As stated by), which states that at the same body weight different carcass compositions can occur between sexes, for example in sheep, the number of female sheep is greater than that of young rams castration and both are larger than male sheep. 
The increase in carcass weight in sheep given in P2 treatment with an average value has the highest average and has a better digestive efficiency, but does not have a significant effect, this is strongly related tothe nutrients contained in the feed and the digestibility level of the feed. Rations that have high nutritional value quickly increase body weight during fattening. states that increasing digestibility in livestock along with decreasing forage in the ration given. To find out the difference in forage use with moiyl fermented cacao pods on feed on male local sheep carcass diversity analysis was carried out in Table 6.

Table 6. Analysis of the variety of weights of male local sheep carcasses

\begin{tabular}{|c|c|c|c|c|c|c|}
\hline \multirow{3}{*}{ SK } & \multirow{3}{*}{ Db } & \multirow{3}{*}{ JK } & \multirow{3}{*}{ KT } & & \multicolumn{2}{|c|}{ F tabel } \\
\hline & & & & & & \\
\hline & & & & F Hitung & $5 \%$ & $1 \%$ \\
\hline Perlakuan & 4 & 3,00 & 0,75 & $3,50 *$ & 3,24 & 5,29 \\
\hline Galat & 15 & 3,21 & 0,21 & & & \\
\hline Total & 19 & 6,22 & & & & \\
\hline
\end{tabular}

The results of diversity analysis in table 6 . show that $\mathrm{F}$ count is greater than $\mathrm{F}$ table so that the use of moiyl fermented cacao pods on feed carcasses of male local sheep has a significantly different effect $(\mathrm{P}<0.05)$ on carcass weight, carcass production is closely related to body weight because the increase in body weight will be followed by an increase in carcass. while increasing age, the carcass weight is likely to be greater, because body weight, body size and other body components also influence carcass weight. According]. there is a large number of rations given, perhaps the growth of a livestock is also good. then it will affect the carcass weight because carcass weight is closely related to the cut weight produced.This can be concluded because each treatment gives a different response to the quality of carcass weight production, because each treatment contains a different composition of feed so that the feed for each treatment responds differently to the production of carcass weight.

\subsection{Carcass Percentage}

The percentage of sheep carcass is obtained from the comparison of carcass weight with empty body weight multiplied by $100 \%$. The average percentage of sheep carcass can be seen in table 7 .

Table 7. Average percentage of male local sheep carcass (\%)

\begin{tabular}{|c|c|c|c|c|c|}
\hline \multirow[b]{2}{*}{ Perlakuan } & \multicolumn{4}{|c|}{ Ulangan } & \multirow[b]{2}{*}{ Rataan } \\
\hline & U1 & $\mathrm{U} 2$ & U3 & $\mathrm{U} 4$ & \\
\hline P0 & 56,93 & 54,77 & 57,57 & 56,78 & $56,51 \pm 1,21$ \\
\hline P1 & 56,79 & 51,43 & 54,07 & 59,94 & $55,55 \pm 3,65$ \\
\hline $\mathrm{P} 2$ & 49,73 & 59,72 & 50,87 & 58,54 & $54,71 \pm 5,14$ \\
\hline P3 & 55,84 & 59,87 & 59,79 & 50,71 & $56,55 \pm 4,32$ \\
\hline $\mathrm{P} 4$ & 49,94 & 49,44 & 53,31 & 53,24 & $51,48 \pm 2,08$ \\
\hline Total & 269,23 & 275,23 & 275,61 & 279,21 & \\
\hline Rataan & 53,84 & 55,04 & 55,12 & 55,84 & 54,96 \\
\hline
\end{tabular}

From table 7. it can be seen that the highest percentage average is found in treatment P3 which is $56.55 \%$ and the lowest average percentage found in treatment P4 is $51.48 \%$ the average is influenced by the average carcass weight, the highest average carcass weight in treatment P2 is equal to $5.74(\mathrm{~kg})$ with the highest percentage of carcass at P3 treatment which is $56.55 \%$. This is also in accordance with the opinion of Sumasprastowo. which states that the percentage of special sheep carcasses was fattened $56-58 \%$, fat sheep $45-55 \%$ and sheep aged $12-16$ weeks $48-50 \%$. The increase in the percentage of carcasses is also in line with the increase in body weight of sheep. This is in accordance 
with the opinionDevendra,which states that carcass is an important factor to assess broiler livestock production. Because it is very closely related to the weight of life where the more weight increases the carcass production will also increase.

The percentage of carcass obtained in this study ranged from $51.48-56.55 \%$ higher than the results of the percentage of carcass obtained by Rianto et al,ranging from 31.57 to $37.10 \%$. Where the weight of slaughter of sheep in my study was $14.73-17.55 \mathrm{~kg}$ while the weight of sheep slaughter by Rianto et al, ranged from $21.20-25.98 \mathrm{~kg}$. The difference in the percentage of carcass results of this study is allegedly due to differences in the quality of feed given. Rianto et al. (2006) used feed with $8.11 \%$ protein content. Livestock that can efficiently use feed protein will increase the protein deposited so that the weight of meat obtained increases and the carcass percentage increases. This is in accordance with Racmadi'sstatement which states that the higher the cut weight, the higher the carcass weight and the higher the carcass percentage. In relation to age factors, increasing the age of livestock which is in line with the growth of live weight increases carcass weight.To find out the difference in the effect of using moiyl fermented cacao pods on the percentage of the weight of male local sheep carcass,adiversity analysis can be carried out in Table 8 .

Table 8. Analysis of the variation in percentage of male local sheep carcasses

\begin{tabular}{ccccccc}
\hline SK & \multirow{2}{*}{ Db } & JK & KT & \multirow{2}{*}{ F Hitung } & \multicolumn{2}{c}{ F tabel } \\
\cline { 6 - 7 } & & & & & $5 \%$ & $1 \%$ \\
\hline Perlakuan & 4 & 69,83 & 17,45 & $1,35^{\mathrm{ln}}$ & 3,24 & 5,29 \\
Galat & 15 & 192,81 & 12,85 & & & \\
\hline Total & 19 & 262,64 & & & & \\
\hline
\end{tabular}

The results of the variance analysis in table 15. show that $\mathrm{F}$ count is smaller than $\mathrm{F}$ table so it is concluded that forage substitution with moiyl fermented cacao pods in feed male local sheep has no significant effect $\mathrm{P}>0.05 \%$ on the percentage of male local sheep carcass. The crude protein content after fermentation often increases due to microbes that have good growth and development, so that the utilization of existing proteins can be digested properly.But fermentation cannot eliminate the existing anti-nutrient substances so that the nutrient content is channeled into the body of the livestock but in a certain period of time and the food consumed is balanced and according to needs. This is consistent with the statement that crude protein content after fermentation often increases due to microbes that have good growth and proliferation, can change more constituent components derived from the microbial body itself which will increase the crude protein content of the substrate .

\section{Conclusions}

The results of the study on cutting weight. empty body weight, carcass weight and percentage of local sheep carcass can be recapitulated in table 9 .

Table 9. Recapitulation of research results

\begin{tabular}{llllll}
\hline \multirow{2}{*}{\multicolumn{1}{c}{ Parameter }} & \multicolumn{5}{c}{ Perlakuan } \\
\cline { 2 - 6 } & P0 & P1 & P2 & P3 & P4 \\
\hline Bobot Potong & $15.70^{\mathrm{III}}$ & $15,98^{\mathrm{tII}}$ & $17,55^{\mathrm{II}}$ & $16,27^{\mathrm{tI}}$ & $14,73^{\mathrm{tI}}$ \\
Bobot Tubuh Kosong & $9,75^{\mathrm{ab}}$ & $10,27^{\mathrm{a}}$ & $10,52^{\mathrm{a}}$ & $10,14^{\mathrm{a}}$ & $9,18^{\mathrm{b}}$ \\
Bobot Karkas & $5,36^{\mathrm{a}}$ & $5,61^{\mathrm{a}}$ & $5,74^{\mathrm{a}}$ & $5,73^{\mathrm{a}}$ & $4,73^{\mathrm{b}}$ \\
Persentase Karkas & $56,51^{\text {tn }}$ & $55,55^{\text {tn }}$ & $54,71^{\text {tn }}$ & $56,55^{\text {tn }}$ & $51,48^{\text {tn }}$ \\
\hline
\end{tabular}

Description: Giving the same notation on each parameter shows the treatment has a significantly different effect $(\mathrm{P}<0.05)$ and is not real (tn)

Based on the results of the recapitulation above, it was found that forage substitution of moiyl fermented cacao pods which were used as feed gave a significant effect $(\mathrm{P}<0.05)$ on empty body weight and carcass weight but not significantly for cut weight and carcass percentage in male local sheep. 


\section{References:}

[1] Syriac, 2007. BeternakDomba. PenebarSwadaya.Jakarta.

[2] Sunanto, 1995. Cokelat, Budidaya,

PengolahanHasildanAspekEkonominya. Kanisius. Yogyakarta.

[3] Cahyono, 1998. Tembakau, BudidayadanAnalisis Usaha Tani,

Kanisius. Yogyakarta

[4] Andiwinarti. R., C.M.S.Lestari,E.Lestari,E. Riyantodan J.A. Prawoto.1999. Karakteristikkarkasdan non karkasdomba yang diberikanpakantambahanlimbah industry kecapdenganaras yang berbeda. Jurnalpengembanganpeternakantropis.

[5] Siregar,S. 1994. Ransum Ternak Ruminansia. Penebar Swadaya. Jakarta.

[6] Yuniarti, 1982. Pertumbuhan-perkembangan saluran pencernaan dan bagian-bagiannya,hati dan pangkreas.Karya Ilmiah. Fakultas Peternakan. Institut Pertanian Bogor. Bogor. 